\title{
PENGEMBANGAN MULTIMEDIA PEMBELAJARAN EKONOMI SMA/MA DENGAN MATERI PERMINTAAN DAN PENAWARAN
}

\author{
Fitria Endang Susana, Muhsinatun Siasah Masruri \\ MAN Sabdodadi Bantul, Universitas Negeri Yogyakarta \\ fit34_end@hyahoo.co.id,muhsinsiasah@gmail.com
}

\begin{abstract}
Abstrak
Penelitian ini bertujuan untuk (1) menghasilkan multimedia pembelajaran ekonomi kelas X SMA/MA dengan materi permintaan dan penawaran dan (2) mengetahui kelayakan dan efektivitas multimedia tersebut untuk meningkatkan hasil belajar ekonomi. Jenis penelitian ini adalah penelitian dan pengembangan yang terdiri atas tiga tahapan, yaitu penyusunan program/konsep, pengembangan produk dan evaluasi. Tahap penyusunan program/ konsep meliputi penentuan tujuan pembelajaran, perumusan materi pembelajaran, penentuan strategi pembelajaran, serta mendesain dan merumuskan evaluasi formatif dan menetapkan aplikasi. Langkah kedua adalah pengembangan produk yang meliputi pembuatan desain media (storyboard dan flowchartview), pengumpulan bahan (material collecting), dan assembly atau pengorganisasian bahan ke dalam tampilan. Proses berikutnya adalah evaluasi produk yang terdiri beberapa tahapan yaitu evaluasi ahli materi dan ahli media, uji coba perorangan, uji coba kelompok kecil, dan uji coba lapangan. Hasil uji coba menunjukkan bahwa rerata skor aspek pemograman sangat baik, materi/isi sangat baik dan aspek media/ tampilan sangat baik. Hasil penelitian menunjukkan bahwa kualitas multimedia pembelajaran ekonomi kelas $\mathrm{X}$ dengan materi permintaan dan penawaran tergolong layak digunakan sebagai media pembelajaran, dan cukup efektif meningkatkan hasil belajar ekonomi.
\end{abstract}

Kata kunci: ekonomi, multimedia

\section{DEVELOPING ECONOMICS MULTIMEDIA FOR THE10 ${ }^{\text {th }}$ GRADE STUDENTS OF SENIOR HIGH SCHOOL/ISLAMIC HIGH SCHOOL FOR TEACHING SUPPLY AND DEMAND}

Fitria Endang Susana, Muhsinatun Siasah Masruri

MAN Sabdodadi Bantul, Universitas Negeri Yogyakarta

fit34_end@hyahoo.co.id, muhsinsiasah@gmail.com

\begin{abstract}
This research aims at: (1) producing a multimedia for economics learning used for the $10^{\text {th }}$ grade students of Senior High School/ Islamic High School on the topic of supply and demand; and (2) finding out the feasibility and effectiveness of the interactive multimedia in improvingthe learning result of economics. This research was a Research and Development (RED) study conducted in three steps: developing/ making a concept, developing a product and evaluating the product. The first step is developing a concept which included identifying and determining the performance objective. The second is learning material, and the teaching strategies, designing the formative assessment, and production, consisting of designing the storyboard and flowchart view, and assembling or organizing the screenview materials. The next process is product evaluation which consisted of some steps: subject-matter and media expert evaluation, individual try out, small group try out, and field try out. The data were collected through a questionnaire and observation. The data are used to know the feasibility of the multimedia. Cognitive tests (pretest and posstest) are used to know the effectiveness of the interactive multimedia. The data were analyzed using the quantitative descriptive technique. The results show the average score on the instructional aspect is very good, on the concept aspect is very good and on the media aspects is very good. From this result the quality of economics multimedia for the $10^{\text {th }}$ grade students on supply and demand materials in terms of the aspects of instruction, content, and media is very good, and succed in achieving the target score.
\end{abstract}

Keywords: ecomonics, multimedia. 


\section{Pendahuluan}

Perkembangan ilmu pengetahuan dan teknologi di segala bidang memberikan pengaruh baik langsung maupun tidak langsung terhadap kualitas pembelajaran. Upaya peningkatan kualitas pembelajaran adalah menjadi tanggungjawab semua pihak yang terlibat dalam dunia pendidikan terutama bagi pendidik, yang merupakan ujung tombak dalam menciptakan sumber daya manusia berkualitas. (Warsita, 2008, p.5) menyatakan bahwa peningkatan kualitas pembelajaran dimaksudkan agar tercapaianya keunggulan dalam proses pembelajaran. Pembelajaran yang unggul merupakan pembelajaran yang mengutamakan hasil dan memberi peluang yang tinggi kepada peserta didik untuk lebih berperan aktif dalam proses pembelajaran.

Pendidik bukan lagi sebagai satusatunya sumber belajar bagi peserta didik. Terdapat sumber belajar lain yang dapat dimanfaatkan agar peserta didik lebih aktif dalam belajar. Peran penting pendidik adalah mengupayakan agar setiap peserta didik dapat berinteraksi dengan sebanyak mungkin sumber belajar. Tugas pendidik yang utama adalah merencanakan, menciptakan dan menemukan kegiatan yang bersifat menantang, yang dapat memotivasi peserta didik untuk berfikir logis dan yang jauh lebih penting adalah mampu menciptakan enjoyable learning, sehingga peserta didik menjadi senang untuk belajar.

Dipandang dari tugas guru yang semakin berat, dimana paradigma pembelajaran mulai bergesar, dari yang semula teacher centered menjadi student centered, dari pola pembelajaran yang berorientasi pada materi ke pembelajaran berbasis kompetensi, yang mensyaratkan pembelajaran model individual, maka pemanfaatan multimedia dapat menjadi alternative sebagai model pembelajaran yang efektif, pembelajaran dengan menggunakan multimedia memungkinkan pembelajaran dapat dilaksanakan secara individual. Penerapan mo- del pembelajaran menggunakan multimedia, bukan berarti menggantikan peran guru, atau motode lain yang relevan dalam pembelajaran, melainkan untuk saling menunjang dan melengkapi guna meningkatkan kualitas hasil pembelajaran, karena pada dasarnya masing-masing materi pembelajaran mempunyai karakteristik yang berbeda satu sama lain.

Hasil pengamatan yang dilakukan pada bulan Desember 2013 pada saat di MAN Sabdodadi Bantul, diketahui bahwa pembelajaran masih mengandalkan variasi metode belajar yang berpusat kepada pendidik (teacher centered teaching), seperti metode ceramah, diskusi, demonstrasi dan eksperimen. Metode ceramah dilaksanakan dengan cara memberikan penjelasan dan contoh oleh pendidi kepada peserta didik menggunakan bahan ajar berupa buku teks, modul, dan LKS. Penggunaan metode pembelajaran ini masih belum mendapatkan hasil yang optimal. Metode diskusi yang dilakukan pendidik dengan menghadapkan peserta didik kepada masalah secara kelompok. Diharapan peserta didik mampu memecahkan masalah bersamasama melalui diskusi kelompok.

Pada kenyataannya metode diskusi kelompok ini tidak begitu efektif dikarenakan mememerlukan waktu yang cukup panjang, padahal waktu pembelajaran di dalam kelas sangat terbatas. Pembelajaran dengan metode demonstrasi maupun dengan eksperimen, meskipun dapat melibatkan peserta didik dalam proses pembelajaran lebih efektif, namun dalam praktiknya kurang efektif dikarenakan pendidik masih tetap lebih banyak beraktivitas ketimbang peserta didik. Hal tersebut disebabkan oleh keterbatasan persediaan peralatan sehingga peserta didik hanya bisa memperhatikan dan mengamati kegiatan yang dilakukan oleh pendidik. Hal ini disinyalir menjadi salah satu penyebab tidak efektifnya proses pembelajaran.

Dipandang dari tugas guru yang semakin berat, di mana paradigma pembelajaran mulai bergesar, dari yang semula teacher centered menjadi student centered, 
dari pola pembelajaran yang berorientasi pada materi ke pembelajaran berbasis kompetensi, dan mensyaratkan pembelajaran model individual, maka pemanfaatan multimedia dapat menjadi alternative sebagai model pembelajaran yang efektif, pembelajaran dengan menggunakan multimedia dapat dilaksanakan secara individual. Penerapan model pembelajaran menggunakan multimedia, bukan berarti menggantikan peran guru, atau motode lain yang relevan dalam pembelajaran, melainkan untuk saling menunjang dan melengkapi guna meningkatkan kualitas hasil pembelajaran. karena pada dasarnya masing-masing materi pembelajaran mempunyai karakteristik yang berbeda satu sama lain.

Suparmoko (1998, p.1) menyatakan bahwa ilmu ekonomi sebagai ilmu yang mempelajari tentang usaha manusia dalam memenuhi kebutuhannya dengan alat-alat pemuas kebutuhan yang langka adanya Luasnya ilmu ekonomi dan terbatasnya waktu yang tersedia membuat standar kompetensi dan kompetensi dasar dibatasi dan difokuskan kepada fenomena empirik ekonomi yang ada disekitar peserta didik, sehingga peserta didik dapat merekam peristiwa ekonomi yang terjadi disekitar lingkungannya dan mengambil manfaat untuk kehidupannya yang lebih baik.

Pemanfaatan media di dalam proses pembelajaran Ekonomi oleh pendidik masih belum optimal, dikarenakan pendidik beranggapan bahwa dengan menggunakan media dalam proses pembelajaran di kelas menyebabkan persiapan dalam mengajar menjadi lebih lama dan menambah beban tugas dalam hal mencari atau membuat media yang sesuai dengan meteri. Permasalahan lain yang dihadapi di MAN Sabdodadi Bantul adalah belum tersedianya software pembelajaran Ekonomi dalam bentuk multimedia interaktif. Penyampaian materi dalam pembelajaran Ekonomi masih menggunakan media cetak seperti buku paket, modul, dan LKS. Disamping itu pendidik belum mampu membuat dan mengembangkan software pem- belajaran multimedia interaktif yang dapat membuat peserta didik tidak hanya memperhatikan media atau objek saja, melainkan juga dituntut untuk berinteraksi selama mengikuti pembelajaran.

Perangkat komputer yang ada di madrasah tersebut belum dimanfaatkan secara maksimal untuk pembelajaran khususnya pembelajaran Ekonomi. Perangkat komputer lebih banyak dimanfaatkan untuk mata pelajaran yang berhubungan dengan teknologi informasi dan komunikasi, serta ketrampilan. Padahal komputer dapat juga digunakan sebagai media pembelajaran yang memiliki banyak kelebihan diantaranya adalah dapat menampilkan berbagai macam objek seperti suara, gambar, grafik dan lain sebagainya yang dapat meningkatkan motivasi dan minat peserta didik dalam mengikuti dan memahami pembelajaran Ekonomi.

Dengan pembelajaran berbasis komputer dapat membantu pembelajar yang memiliki kecepatan belajar lambat (slow learner) karena kemampuan komputer untuk menayangkan kembali informasi yang diperlukan sedangkan bagi pembelajar yang lebih cepat (fast learner) dapat memacu aktifitas belajar. Berbagai permasalahan tersebut turut berpengaruh terhadap tingkat ketuntasan hasil belajar siswa yang masih rendah sehingga seringkali para guru harus melakukan kegiatan remedial untuk mengatasinya. Hasil wawancara dengan guru Ekonomi di MAN Sabdodadi Bantul menyebutkan sekitar $70 \%$ siswa belum mencapai ketuntasan maksimal dalam proses pembelajaran untuk mata pelajaran Ekonomi dan hanya sekitar 30\% siswa yang mampu memperoleh nilai yang memuaskan dengan mengacu kepada hasil-hasil tugas dan ulangan yang diberikan oleh guru Ekonomi. Rendahnya hasil belajar siswa terutama pada materi-materi yang abstrak, seperti pada materi permintaan dan penawaran.

Menyikapi permasalahan tersebut, maka dalam pembelajaran Ekonomi dirasa perlu dilakukan pembaharuan terkait dengan proses pembelajaran yang memper- 
hatikan aktifitas peserta didik untuk belajar mandiri dan pemanfaatan media yang dapat memberikan interaktifitas bagi peserta didik dalam proses pembelajaran. Salah satu alternative dengan mengoptimalkan proses pembelajaran menggunakan multimedia interaktif dalam pembelajaran Ekonomi yang dikemas ke dalam CD. Hal ini sesuai keunggulan multimedia dibandingkan dengan media lain, (Daryanto, 2010, p.53) menyatakan keunggulan multimedia diantaranya adalah: (1) memiliki lebih dari satu media yang konvergen, misalnya menggabungkan unsur audio dan visual; (2) bersifat interaktif, dalam pengertian memiliki kemampuan untuk mengakomodasi respon pengguna; dan (3) bersifat mandiri, dalam pengertian memberi kemudahan dan kelengkapan isi sedemikian rupa sehingga pengguna bisa menggunakan tanpa bimbingan orang lain.

Penggunaan CD multimedia ekonomi ini diharapkan dari segi waktu dan kejelasan materi pembelajaran dapat tersampaikan dengan baik. Keindahan, kemenarikan dan adanya interaktifitas dalam suatu media pembelajaran merupakan sarana agar peserta didik tidak jenuh dalam mengikuti pelajaran dan efek yang terbesar diharapkan peserta didik dapat termotivasi dan mempermudah dalam menerima materi pelajaran . Selain itu, belajar dapat dilakukan disekolah maupun di rumah.

\section{Metode Penelitian}

Penelitian ini merupakan jenis penelitian dan pengembangan atau Research and Development (R\&D). Tujuan akhir dari penelitian pengembangan ini adalah menghasilkan produk multimedia yang berkualitas untuk pembelajaran ekonomi dengan materi permintaan dan penawaran bagi siswa kelas X SMA/MA. Sebagai acuan dalam pengembangan multimedia ini, digunakan model pengembangan LutherSutopo. Model ini dipilih karena menurut hemat penulis modelnya sederhana, lengkap dan mudah diterapkan.
Langkah-langkah pengembangan yang menjadi landasan dalam pengembangan seperti disajikan pada Gambar1.

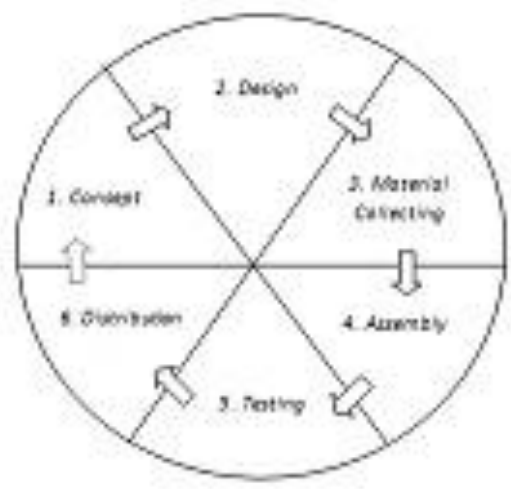

Gambar 1. Model Pengembangan Luther-Sutopo

Bintoro (2010, pp.259-263) menjelaskan masing-masing elemen model pengembangan tersebut adalah sebagai berikut: Pertama, Concept, pada tahap concept langkah yang dilakukan adalah menentukan tujuan, pembelajaran, mengidentifikasi audiens, macam aplikasi, tujuan aplikasi, dan spesifikasi umum. Adapun hal-hal yang perlu diperhatikan adalah menentukan tujuan dan memahami karakter user. Kedua, Design, pada tahap ini pengembang membuat spesifikasi secara rinci mengenai arsitektur proyek, gaya dan kebutuhan material untuk proyek jenis aplikasi tutorial. pembuatan design pada pengembangan multimedia ini menggunakan perangkat: storyboard dan flowchartview. Storyboard merupakan deskripsi dari setiap tampilan yang secara jelas menggambarkan objek multimedia serta perilakunya, sedangkan flowchartview adalah diagram yang memberikan gambaran alur dari suatu tampilan lainnya.

Ketiga, material collecting, pada tahap ini pengembang mengumpulkan bahan untuk pembuatan multimedia, misalnya gambar, suara, film atau video, filefile animasi, dan sebagainya. Keempat, assembly, pada tahap ini pengembang mengintegrasikan semua materi yang telah dibuat ke dalam screen, sesuai dengan storyboard yang telah dibuat. Kegiatannya 
adalah mentrasfer semua komponen yang telah dibuat, ke dalam screen dengan menggunakan Adobe Flash CS3. Kelima, testing, tahap ini dilakukan dengan melakukan evaluasi dari ahli materi dan ahli media, serta serangkaian proses uji coba kepada peserta didik. Kegiatan yang dilakukan pada tahap evaluasi adalah melakukan uji coba menggali data tentang tanggapan responden mengenai kualitas multimedia pembelajaran yang dikembangkan, kemudian berdasarkan hasil evaluasi tersebut, multimedia pembelajaran direvisi, sampai terwujud multimedia pembelajaran yang berkualitas ditinjau dari aspek kualitas isi, kualitas instruksional dan kualitas teknis; Keenam, Distribution (penyebaran dan implementasi), pada tahap ini, produk media yang telah teruji kualitasnya disebarluaskan, dan dapat dimanfaatkan untuk pembelajaran.

Penilaian media dilakukan oleh ahli materi dan ahli media. Penilian ini dijadikan masukan untuk perbaikan media. Uji coba dilakukan untuk mengumpulkan data tentang kualitas multimedia yang telah dibuat. Data dari hasil uji coba, dianalisis dan dijadikan sebagai bahan pertimbangan untuk memperbaiki dan menyempurnakan multimedia yang dikembangkan. Uji coba yang dilakukan antara lain uji coba perorang, kelompok kecil dan uji coba lapangan. Penelitian dilakukan di MAN Sabdodadi Bantul, pada bulan April sampai dengan bulan Juni 2014. Populasi penelitian adalah siswa kelas X MAN Sabdodadi Bantul tahun ajaran 2013/2014 sebanyak 183 siswa, sedangkan subjek uji coba untuk uji coba perprangan sebanyak 3 orang siswa. Uji coba kelompok kecil sebanyak 12 siswa dan ujicba lapangan sebanyak 93 siswa.

Menurut Walker dan Hess, dalam (Azhar, 2009, pp.176-177) menilai kualitas perangkat lunak media pembelajaran dapat dilihat dari tiga sisi, yaitu kualitas isi, kualitas instruksional, dan kualitas teknis (media). Instrumen yang digunakan untuk mengumpul data tentang kualitas multimedia digunakan angket, dan untuk me- ngumpulkan data tentang keefektifan media megunakan soal tes kognitif. Uji coba instrumen dilakukan dengan maksud unutk mendapatkan informasi mengenai validitas dan reliabilitas sebagai bahan pertimbangan dalam melakukun revisi atau mengganti butir-butir instrumen yang akan digunakan sebagai alat ukur dalam penelitian. (Sukardjo, 2010, p.58) menyatakan kriteria untuk menentukan butir tes evaluasi yang perlu diperbaiki, atau diganti didasarkan pada 3 parameter yaitu: tingkat kesukaran, validitas, dan reliabilitas serta daya pembeda soal. Tingkat kesukaran untuk butir soal obyektif adalah proporsi siswa yang menjawab benar untuk butir tertentu.

Variabel yang hendak diukur dalam penelitian ini adalah kualitas multimedia, prestasi hasil belajar yang dilihat dari kenaikan skor posttest terhadap pre-test dan pencapaian target kompetensi. Data kualitas multimedia berupa data kualitatif, yakni berupa tanggapan ahli media, ahli materi dan tanggapan siswa atas kualitas multimedia, sedangkan data prestasi belajar siswa, berupa data kuantitatif, yakni berupa skor tes awal dan skor tes akhir.

Dalam penelitian pengembangan ini diperoleh 5 jenis data, yaitu: data tentang kualitas multimedia oleh ahli media, data tentang kualitas multimedia oleh ahli materi, data hasil uji coba perorangan (3 orang siswa), data hasil uji coba kelompok kecil (12 siswa) dan data hasil uji coba lapangan.

Dalam evaluasi multimedia pembelajaran, ahli materi menitikberatkan pada aspek materi yang terdapat dalam multimedia dan aspek pembelajaran. Sedangkan ahli media menitikberatkan pada evaluasi aspek media yang meliputi tampilan dan pemprograman. Hasil evaluasi ahli media dan ahli materi digunakan untuk merevisi dan mengukur kelayakan multimedia yang akan diujicobakan dilapangan. Uji coba perorangan dan kelompok kecil dimaksudkan untuk mengidentifikasi permasalahan awal yang terjadi ketika multimedia digunakan. Melalui 
identifikasi ini diharapkan saat uji coba dilapangan tidak ditemukan permasalahan yang mendasar yang dapat mengganggu proses uji coba lapangan. Data uji coba tahap ini digunakan sebagai bahan masukan untuk melakukan revisi terhadap produk.Uji coba lapangan menghasilkan datadata yang nantinya akan digunakan untuk mengukur kualitas multimedia yang dikembangkan, mengukur efektifitas multimedia untuk meningkatkan prestasi belajar siswa dilihat dari kenaikan skor posttest terhadap pretest dan ketercapaian kompetensi. Oleh karena itu pada uji coba lapangan diperoleh tiga macam data, yaitu data tentang penilaian siswa mengenai kualitas multimedia, data skor pretest dan data skor posttest dengan menggunakan multimedia interaktif ekonomi untuk kelas X SMA/MA.

Teknik Analisis Data

Variabel yang hendak diukur dalam penelitian ini adalah kualitas multimedia, prestasi hasil belajar yang dilihat dari kenaikan skor posttest terhadap pretest dan pencapaian target kompetensi. Data kualitas multimedia berupa data kualitatif, yakni berupa tanggapan ahli media, ahli materi dan tanggapan siswa atas kualitas multimedia, sedangkan data prestasi belajar siswa, berupa data kuantitatif, yakni berupa skor tes awal dan skor tes akhir.

Menurut Sukardjo (2010, p.101) untuk menganalisis data tentang kualitas multimedia dilakukan langkah-langkah sebagai berikut: (1) data tanggapan responden tentang kualitas multimedia yang masih dalam bentuk nilai huruf, diubah menjadi bentuk angka sebagai yaitu sangat baik (SB) skor 5, baik skor 4, cukup 3, kurang baik skor 2 dan sangat kurang baik skor 1; (2) Mencari jumlah dan rata-rata empirisnya, dengan rumus berikut.

$$
\bar{x}=\frac{\sum X}{n}
$$

Dimana $\bar{X}$ merupakan skor ratarata, $\sum X$ jumlah skor dan $\mathrm{n}$ adalah jumlah responden; dan (3) Untuk mengetahui kualitas multimedia, rerata skor empiris dikonversikan dengan skala 5 , Teknik analisis data menggunakan statistik deskriptif yang kemudian dikonversikan menjadi data kualiatatif skala 5 dengan menggunakan acuan konversi dari (Sukardjo, 2010, p.101)

Tabel 1. Konversi Skor pada Skala 5

\begin{tabular}{lcl}
\hline Skor & Nilai & Kategori \\
\hline $\bar{X}_{L} \div 1,80 S B i<X$ & A & Sangat baik \\
$\bar{X}_{l} \div 0,60 S B i<X \leq \bar{X} \div 1,80 S B i$ & B & Baik \\
$\bar{X}_{L}-0,60 S B i<X \leq \bar{X} \div 0,60 S B i$ & C & Cukup \\
$\bar{X}_{l}-1,80 S B i<X \leq \bar{X}-0,60 S B i$ & D & Kurang \\
$X \leq \bar{X}-1,80 S B i$ & E & Sangat kurang \\
\hline
\end{tabular}

Keterangan : $\bar{X}$ merupakan rerata skor ideal yang dicari dengan cara $\frac{1}{2}$ (skor mak ideal + skor min ideal), $S B_{i}$ merupakan simpangan baku ideal yang dicari dengan cara $\frac{1}{6}$ (skor mak ideal- skor min ideal), $X$ adalah skor aktual

Berdasarkan rumus konversi seperti disajikan pada Tabel 1, untuk mengubah data kuantitatif ke dalam data kualitatif, digunakan pedoman konversi sebagai terlihat pada Tabel 2.

Tabel 2. Pedoman Konversi Data Kuantitatif ke Data Kualitatif pada Skala 5

\begin{tabular}{lcl}
\hline Interval skor & Nilai & Kategori \\
\hline $4,08<X$ & A & Sangat baik \\
$3,36<X \leq 4,08$ & B & Baik \\
$2,64<X \leq 3,36$ & C & Cukup \\
$1,92<X \leq 2,64$ & D & Kurang \\
$X \leq 1,92$ & E & Sangat kurang \\
\hline
\end{tabular}

Data dan saran konkret dari responden, dihimpun dan disarikan untuk memperbaiki multimedia. Efektivitas multimedia terhadap peningkatan hasil belajar ekonomi peserta didik diketahui melalui penilaian hasil belajar kognitif yang dilakukan dengan cara mengukur skor peningkatan hasil belajar kognitif. Hasil belajar kognitif dari hasil pretest dan postest yang berupa data kuantitatif dilakukan 
perhitungan besarnya effect size dan melihat ketercapaian kriteria ketuntasan minimal (KKM) peserta didik. Adapun standar KKM di MAN Sabdodadi Bantul untuk pembelajaran Ekonomi pada materi permintaan dan penawaran adalah "70".

\section{Hasil Penelitian dan Pembahasan}

Hasil Pengembangan

Untuk menghasilkan produk multimedia dilakukan beberapa langkah antara laian (1) pengembangan program pembelajaran, pada tahap pengembangan program pembelajaran, peneliti melakukan kegiatan yang pertama adalah menentukan SK yaitu SK yang ke-3 tentang memahami konsep ekonomi yang kaitannya dengan permintaan, penawaran, harga keseimbangan pasar. Kedua, melakukan analisis dan menetapkan KD yaitu KD ke-3.1, 3.2, dan 3.3. KD 3.1 tentang mengidentifikasi faktor-faktor yang mempengaruhi permintaan dan penawaran, KD ke 3.2 tentang menjelaskan hukum permintaan dan hukum penawaran serta asumsi yang mendasarinya, dan KD 3.3 tentang mendeskripsikan. pengertian harga dan jumlah keseimbangan. Ketiga, menentukan materi pembelajaran yaitu materi permintaan dan penawaran. Keempat, mengembangkan instrumen penilaian yaitu dalam bentuk tes hasil belajar kognitif berupa pilihan ganda. Kelima, menganalisis kebutuhan dan karakteristik peserta didik kelas $\mathrm{X}$ yang rata-rata berusia 15 tahun yang berada pada tahap formal operasional yang ditandai dengan siswa sudah mampu berpikir abstrak dan logis dengan menggunakan pola pikir "kemungkinan". Keenam, menetapkan jenis aplikasi multimedia, dipilih multimedia interaktif, layout dasar, pemilihan warna dan jenis font, sistem distribusi media menggunakan CD dan program yang digunakan menggunakan Adobe Flash CS3.

(2) Design. Pada tahap design pengembang membuat flowchart dan storyboard sebagai tampilan atau gambaran suatu multimedia interaktif yang akan diproduksi. Flowchart media dapat dilihat pada gambar 2 .

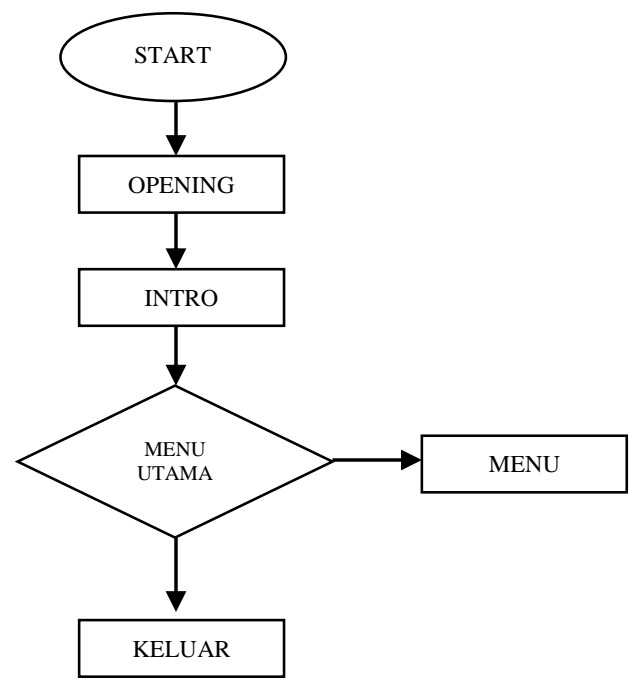

Gambar 2. Flowchart Multimedia Ekonomi Kelas X SMA/MA

Setelah pembuatan flowchart dilanjutkan dengan pembuatan storyboard, seperti terlihat pada Gambar 3.

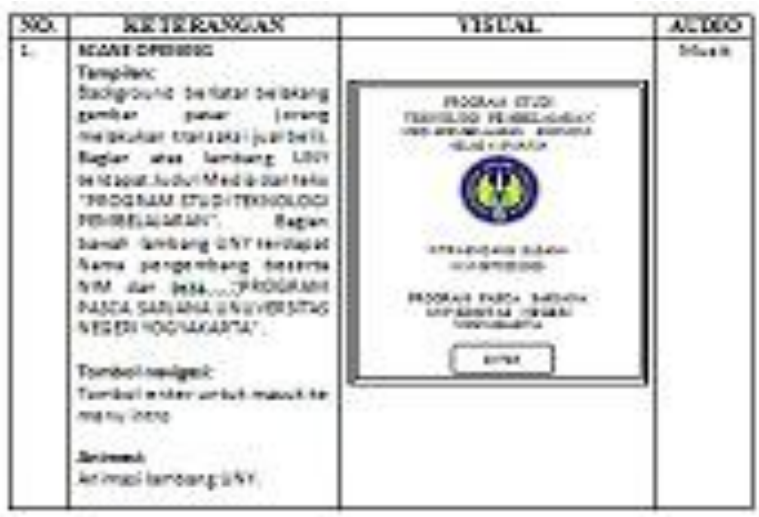

Gambar 3. Storyboard Multimedia Ekonomi

(3) Material Collecting, pada tahap ini dikumpulkan bahan-bahan yang diperlukan untuk pembuatan media, seperti: menyiapkan musik instrument, menyiapkan gambar yang dapat mendukung media seperti gambar kegiatan jual beli, menyiapkan video tentang materi permintaan dan penawaran serta keseimbangan pasar. Terdapat 2 video yang diperlukan pada pembuatan media antara lain video berita yang berkaitan langsung dengan materi dan video tentang keseimbangan pasar. 
Video terbut diambil dari berita "Liputan 6 SCTV" dan keseimbangan pasar dari "tve", pembuatan animasi pembentukan kurva permintaan dan penawaran.

(4) Assembly, pada tahap ini pengembang mengintegrasikan semua materi yang telah dibuat ke dalam screen sesuai dengan flowchart dan storyboard yang telah dibuat. Kegiatannya adalah mentranfer semua komponen yang telah dibuat, ke dalam screen dengan Adobe Flash CS3. Contoh sceen pada program Adobe Flash CS3.

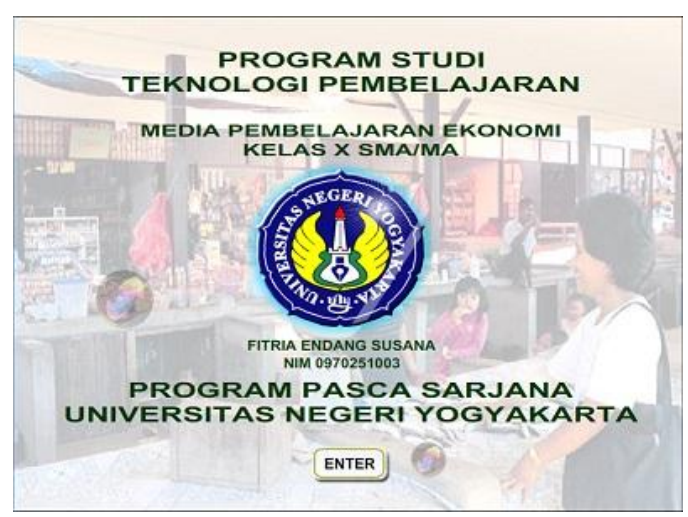

Gambar 4. Tampilan media dengan Adobe flash CS3

(5) Testing, pada tahap testing atau evaluasi produk, peneliti melakukan kegiatan antara lain pertama review dari ahli materi melalui angket yang kemudian dianalisis hasil penilaian ahli materi yang digunakan untuk merevisi multimedia berdasarkan kritik dan saran ahli materi, kedua Review dari ahli media melalui angket yang kemudian dianalisis hasil penilaian ahli media yang digunakan untuk merevisi multimedia berdasarkan kritik dan saran ahli media,ketiga uji coba perorangam yang melibatkan 3 siswa, dari uji coba perorangan peserta didik menilai mulmitedia melalui angket dari hasil penilaian 3 orang siswa dilakukan analisis dan revisi sesuai dengan kritik dan saran dari peserta didik, keempat uji coba kelompok kecil, yang melibatkan 12siswa, siswa menilai mulmitedia melalui angket. Dari hasil penilaian 12 siswa dilakukan analisis dan revisi sesuai dengan kritik dan saran dari siswa. Kelima uji coba lapangan yaitu peneliti meng- ujicobakan multimedia interaktif kepada peserta didik pada seting lingkungan pembelajaran yang sebenarnya. Uji coba lapangan dilakukan pada 3 kelas dengan jumlah peserta didik 93 siswa.

(6) Penyebaran dan Implementasi. Produk multimedia yang telah selesai dikemas dalam CD yang dapat digunakan dalam kegiatan pembelajaran.

\section{Hasil Uji Coba Produk}

Penilaian ahli materi pada aspek pembelajaran maupun isi termasuk kategori baik. Jumlah rerata skor ahli materi untuk aspek pembelajaran 32,5 dengan skor rerata 4,06 kategori baik, begitu pula aspek isi jumlah rerata skor dari dua ahli materi adalah 48,5 dengan skor rerata 4,04 kategori baik. Sedangkan penilaian ahli media pada aspek pemprograman maupun tampilan termasuk kategori baik dan sangat baik. Jumlah rerata skor ahli media untuk aspek pemprograman 28,5 dengan skor rerata 4,07 kategori baik, begitu pula aspek tampilan jumlah rerata skor dari dua ahli media adalah 49,5 dengan skor rerata 4,13 kategori sangat baik.

Data uji coba perorangan aspek rerata skor aspek pembelajaran adalah 4,38 kategori sangat baik, rerata skor aspek materi adalah 4,38 kategori sangat baik dan aspek media rerata skor 4,22 kategori sangat baik. Data uji coba kelompok kecil rerata skor aspek pembelajaran adalah 4,38 termasuk kategori sangat baik, aspek materi rerata skor 4,13 termasuk kategori sangat baik dan untuk aspek media rerata skor 4,26 termasuk kategori sangat baik. Pada uji coba lapangan didapatkan rerata skor aspek pembelajaran 4,32. Rerata skor aspek materi 4,20 dan rerata skor aspek media adalah 4,29. Data prestasi belajar siswa pada uji coba lapangan terdiri dari skor pretest dan posttest.

Hasil penelitian menunjukkan Hasil analisis data pada uji coba lapangan juga menunjukkan bahwa kualitas multimedia pembelajaran ekonomi kelas $X$ SMA/MA dengan materi permintaan dan penawaran ditinjau dari aspek pembelajar- 
an, materi dan tampilan adalah sangat baik dengan perolehan rerata skor untuk masing-masing aspek. Ditinjau aspek pembelajaran adalah sangat baik dengan rerata skor 4,32 (sangat baik), ditinjau dari aspek materi adalah sangat baik dengan rerata skor 4,20 (sangat baik) dan ditinjau dari aspek media adalah sangat baik dengan rerata skor 4,29 (sangat baik).

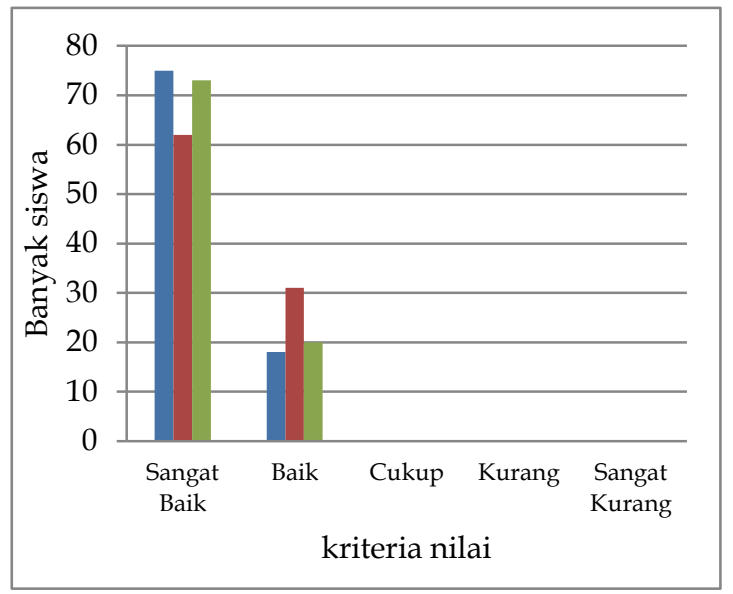

Gambar 5. Histogram Kualitas Multimedia Pembelajaran Ekonomi

Berdasarkan skor tes kognitif, multimedia pembelajaran ekonomi kelas $\mathrm{X}$ SMA/MA dengan materi permintaan dan penawaran cukup efektif untuk menaikkan skor posttest terhadap prerest, namun belum efektif untuk pencapaian target kompetensi. Kenaikan skor posttest terhadap pretest sebesar $63,86 \%$ (rerata skor pretest 43,44 dan rerata posttest 71,18. Dari 93 siswa peserta uji coba, siswa yang mencapai ketuntasan belajar sebanyak 73,33\% .

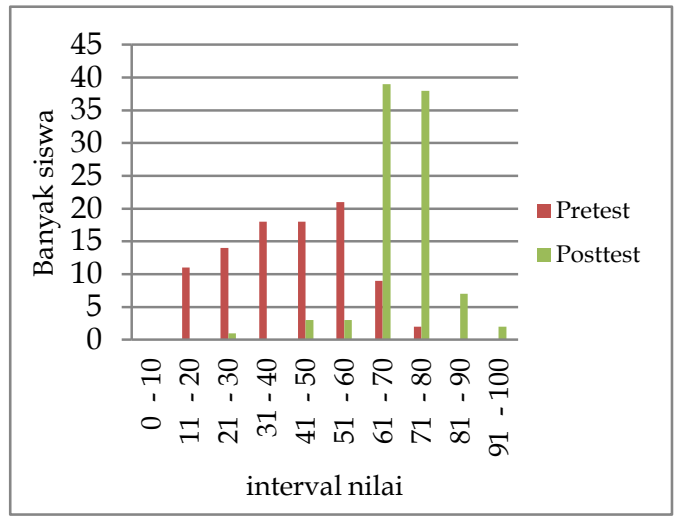

Gambar 6. Histogram Distribusi Frekuensi Nilai Siswa

\section{Simpulan dan Saran}

Simpulan

Simpulan dari hasil penelitian ini antara lain (1) Kualitas multimedia interaktif mata pelajaran ekonomi kelas $\mathrm{X}$ dengan materi permintaan dan penawaran tergolong layak digunakan sebagai media pembelajaran. Dari hasil uji coba dapat diperoleh rerata skor dari aspek pemrograman sebesar 4,32 (sangat baik), materi/ isi sebesar 4,20 (sangat baik) dan aspek media/ tampilan sebesar 4,29 (sangat baik) (2) Multimedia pembelajaran ekonomi kelas $\mathrm{X}$ dengan materi permintaan dan penawaran terbukti cukup efektif meningkatkan prestasi belajar siswa, dilihat dari kenaikan skor posstest terhadap pretest. Hasil analisis menunjukkan kenaikan skor posstest terhadap pretest sebesar 63,86\% (rerata prestest 43,44 dan rerata skor posttest 71,18). Dari 93 siswa peserta uji coba, siswa yang mencapai ketuntasan belajar hanya $73,33 \%$ (66 siswa).

\section{Saran}

Saran pemanfaatan produk adalah sebagai berikut. Pertama, bagi pendidik hendaknya memberikan pengarahan terlebih dahulu kepada peserta didik yang baru pertama kali menggunakan multimedia secara mandiri tentang cara penggunaannya walaupun multimedia interaktif ini di desain untuk pembelajaran mandiri bagi peserta didik dan sudah dilengkapi dengan fasilitas menu petunjuk penggunaan. Kedua, bagi sekolah, untuk pemanfaatan multimedia interaktif ini dalam pembelajaran diperlukan laboratorium komputer multimedia dengan komputer yang memiliki spesifikasi perangkat keras minimal sebagai berikut: processor Intel Pentium III 450 megahertz, hard disk minimal 10 gigabyte, compact disc-read only memory (CD-ROM) drive $52 \times$ speed, Random Acces Memory (RAM) minimal 128 megabyte, Video Graphics Array (VGA) 32 megabyte, resolusi monitor 1024 x 768 pixel dengan kedalaman warna 32 bit, spekeaker aktif. Sehingga multimedia 
interaktif dapat berfungsi dan memberikan manfaat secara optimal. Ketiga, agar pencapaian kompetensi dapat optimal (100\%), maka dalam pembelajaran, disamping menggunakan multimedia hendaknya diiringi pula dengan penggunaan metode pembelajaran lain yang relevan. Keempat, perlu dilakukan penelitian lebih lanjut mengenai efisiensi multimedia ini untuk pembelajaran, misalnya dengan penelitian experiment atau dengan penelitian tindakan kelas.

Multimedia interaktif ini dapat didesiminasikan melalui kerja sama dengan dinas pendidikan pemerintah terkait, melalui musyawarah pendidik mata pelajaran (MGMP) Ekonomi, pelatihan tentang media pembelajaran bagi pendidik SMA/MA, dan melalui berbagai forum lainnya sehingga multimedia interaktif yang dikembangkan ini dapat digunakan oleh seluruh sekolah SMA/MA, khususnya untuk pembelajaran Ekonomi kelas $X$ de- ngan materi permintaan dan penawaran dalam hal meningkatkan hasil belajar peserta didik.

\section{Daftar Pustaka}

Azhar, A. (2009). Media pembelajaran. Jakarta: PT Rajawali Pers.

Bintoro, I. (2010). Multimedia digital- dasar teori dan pengembangannya. Yogyakarta: Andi Offset

Daryanto. (2010). Media pembelajaran. Yogyakarta: Gava Media.

Sukardjo. (2010). Evaluasi pembelajaran. Hand-out perkuliahan: PPs Universitas Negeri Yogyakarta

Warsita, B. (2008). Teknologi pembelajaran; landasan \& aplikasinya. Jakarta: Rineka Cipta. 